\author{
О.В. Олійник, д.е.н., проф. \\ В.В. Ксендзук, к.е.н., доц. \\ Державний університет «Житомирська політехніка»
}

\title{
Державна зовнішньоторговельна політика як об'скт дослідження в наукових працях українських та закордонних дослідників
}

\begin{abstract}
Актуальність теми дослідження пов'язана зі зростанням публікаційної активності в сфері зовнішньоторговельної політики та трунтується на здійсненні аналізу таких публікацій у найбільшій у світі реферативній базі даних Scopиs. Метою є характеристика напрямів дослідження в сфері державного управління зовнішньоторговельною діяльністю, щьо реалізується на основі використання методу бібліометричного аналізу наукових досліджень у міжнародній наукометричній базі Scopus. Здійснення аналізу дозволило окреслити предметно-об'єктну сферу зовнішньоторговельної політики в різні періоди протягом 1974-2020 рр. Позитивна тенденція зростання кількості публікацій у базі Scopиs за досліджуваною тематикою підтверджується тим фактом, щуо дослідження в сфері публічного управління активізувалися в 80-х роках XX $\mathrm{cm}$. В иілому за досліджуваний період найбільше статей опубліковано за такими галузями, як: економіка, економетрика, фінанси, соціальні науки, що становить майже половину наукових досліджень у сфері зовнішньоторговельної політики. Дослідження в 1974-1979 рр. присвячені розкриттю проблем зовнішньої торгівлі та формуванню напрямів зовнішньої політики країн світу в сфері наук про навколишнє середовище та наук про землю і планети. Натомість сучасні наукові пошуки (2016-2020 рр.) стосуються таких проблем, як: управління ланцюгами поставок, участь країн в глобальних ланиюгах створення вартості, діджиталізація торгівлі, торговельні війни, щзо супроводжується ризиками зовнішньоторговельної діяльності. Проаналізовано зв'язки між основними ключовими термінами, щзо зустрічаються в досліджуваній тематиці, та сформовано 6 кластерів (світова торговельна політика; зовнішня торгівля СС та США; наслідки зовнішньої торгівлі на соціо-еколого-економічну світову систему; стратегічні напрями розвитку зовнішньої торгівлі; принциипи СОТ та політика країн-учасниць; політика протекціонізму (тарифні та нетарифні методи). Визначено, щзо завданням публічного сектору є формування ефективних механізмів державного управління зовнішньоторговельною діяльністю на підставі виявлення проблемних питань у сфері зовнішньої торгівлі та застосування результатів зовнішньої політики краӥни.
\end{abstract}

Ключові слова: бібліометричний аналіз; зовнішньоторговельна політика; державна політика, експорт; імпорт; Україна; база даних Scopиs.

Актуальність теми. Глобалізаційні процеси в світі призводять до того, що господарські процеси виходять за межі національних економічних систем, і постає необхідність у розвитку та удосконаленні механізмів державного регулювання зовнішньоторговельною діяльністю. Дослідження, що здійснюються в цьому напрямі, мають різносторонні аспекти та характеризуються мультидисциплінарністю (управління, політологія, соціологія, економіка). Публічне управління як об'єкт наукового дослідження з'явилося не так давно та на сьогодні є досить актуальним. Враховуючи той факт, що участь держави в господарських процесах посилюється під впливом дії непередбачуваних факторів, зокрема, зміни, які спостерігаються у зв'язку з впровадженням карантинних обмежень через поширення коронавірусу, вимагають застосування нових методів державного управління та удосконалення й адаптації існуючих до змінних умов зовнішнього і внутрішнього середовища.

Публічне управління як окремий напрям наукових досліджень у світі з’явився у 1980-х pp. Виокремлення цієї дисципліни було ініційовано американськими дослідниками від різних наукових напрямів, зацікавлених у поєднанні досягнень дослідницьких підходів, які вони представляють, в одну дисципліну управлінських наук. В той час в Україні, як в одній з республік Радянського Союзу, спостерігалася негативна тенденція зниження зовнішньоторговельного обороту, що було спричинено застосуванням комуністичних принципів в управлінні державою та недооцінюванням ролі зовнішньої торгівлі як чинника економічного розвитку. Лише в роки перебудови економіки (1987-1991 рр.) відбувалася ліквідація державної монополії на зовнішню торгівлю та зміна принципів управління зовнішньоекономічної діяльності. Як галузь науки в Україні державне управління отримало визнання лише в 1996 р., коли наказом Вищої атестаційної комісії України від 13 березня 1997 р. № 86 був затверджений перелік наукових спеціальностей цієї галузі.

Метою статті $\epsilon$ характеристика напрямів дослідження в сфері державного управління зовнішньоторговельною діяльністю, що реалізується на основі використання методу бібліометричного 
аналізу наукових досліджень у міжнародній наукометричній базі Scopus. Це дозволить окреслити предметно-об'єктну сферу зовнішньоторговельної політики та сприятиме формуванню підстав удосконалення державної політики в цій сфері.

Аналіз останніх досліджень та публікацій, на які спирається автор. Дослідження в сфері державного управління зовнішньоекономічними процесами здійснювали такі науковці, як: Борисенко О.П. (2013), Коліжук О.О. (2012), Коршунова Г.С. (2000), Крупін В.С. (2008), Литвин Н.Ю. (2014), Машков А.О. (2014), Онищенко О.А. (2008), Пісьмаченко Л.М. (2008), Скрябіна Д.С. (2014), Філіна Г.І. (2003), Яворський А.І. (2002). Науковці в своїх дисертаційних дослідженнях здійснили обгрунтування механізмів державного управління зовнішньоекономічною діяльністю. Варто зауважити, що в цій предметній області дослідження не було здійснено грунтовного аналізу бази Scopus. Враховуючи той факт, що міжнародна наукометрична база на сьогодні займає провідне місце в науковому середовищі та об'єднує найбільш цитовані та значущі в науці видання, доцільно керуватися напрямами дослідження, що висвітлюються в цій базі.

Викладення основного матеріалу. Глобалізаційні процеси в світі сприяють розвитку зовнішньої торгівлі країн, тому цей напрям має безліч питань і проблем, які активно обговорюються на різних зустрічах - від засідань Генеральної Асамблеї ООН до національних наукових конференцій, круглих столів, семінарів та тренінгів. Масиви інформації, що характеризують зовнішньоторговельні відносини, настільки великі та різносторонні, що їх аналіз та узагальнення стають неактуальні з врахуванням тих змін, які відбуваються в середовищі. В дослідженні нами використано метод бібліометричного аналізу 3 метою систематизації напрямів наукових досліджень у сфері зовнішньоторговельної політики країн світу та здійснення оцінки ступеня досліджуваності цієї проблематики в різних країнах у різні періоди часу. Поняття «бібліометрія» характеризується як «науковий напрям, заснований на методах кількісного аналізу бібліографічних характеристик документів, що дають основу для їх якісної оцінки» [1, с. 16]. Медведєва А. зазначає, що «комплексність охоплення й інтерпретації характеристик літератури, що первісно притаманні бібліометрії як якісно новій формі її аналітико-синтетичної обробки документальних інформаційних потоків, роблять іiі комунікаційним посередником, що спрямований на вирішення питань пошуку та змістового оцінювання інформації, а також визначення подальших напрямів наукових досліджень» [3].

Для проведення вказаного методу аналізу наукових досліджень обрано міжнародну наукометричну базу Scopus. Вона $є$ найбільшою у світі реферативною базою даних та наукометричною платформою, яку створено у 2004 р. видавничою корпорацією Elsevier (заснована у 1880 р., м. Амстердам, Нідерланди). База даних Scopus індексує наукові журнали, матеріали конференцій та серійні книжкові видання. Scopus індексує назви наукових видань з технічних, медичних та гуманітарних наук. Розробником та власником SciVerse Scopus є видавнича корпорація Elsevier [2].

3 метою виокремлення ключових слів, за якими здійснювався аналіз наукових досліджень за темою, використано публічний додаток Google Trends [10], що використовує ресурси пошукової системи Google та показує частоту пошуку і популярність певного терміна по відношенню до загального обсягу пошукових запитів у різних регіонах світу та різними мовами. Таким чином, виявлено тенденцію (рис. 1), що такі поняття, як «trade policy», «foreign trade», «public policy», «international trade» протягом останніх 15 років (2004-2020рр.) мають подібну динаміку популярності.

150

100

50

0

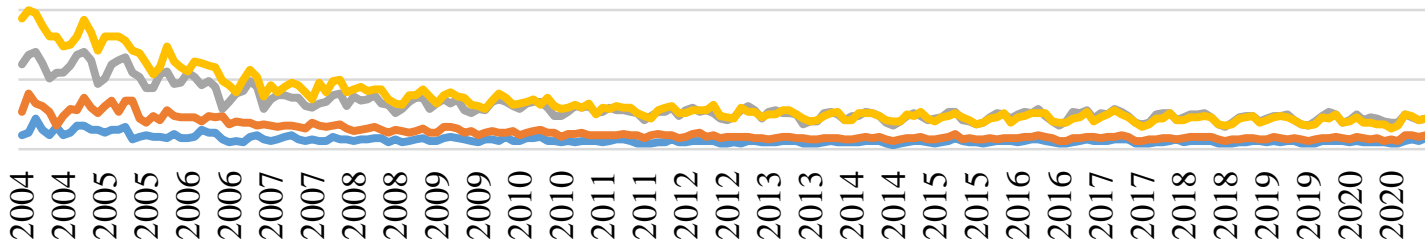

$\longrightarrow$ trade policy $\longrightarrow$ foreign trade $\longrightarrow$ public policy $\longrightarrow$ international trade

Джерело: складено з використанням додатка Google Trends [10]

Pис. 1. Динаміка частоти пошуку в системі Google термінів «trade policy», «foreign trade», «public policy», «international trade» у системі за період 2004-2020 pp.

Розглядаючи наведену тенденцію популярності досліджуваних понять у пошуковому середовищі, проаналізовано також географічну динаміку їх популярності. Так зокрема в країнах Північної Америки більше запитів здійснювалося за такими ключовими словами, як «trade policy» та «public policy». Тоді як в країнах Західної Свропи, Азії та Африки спостерігається найбільша пошукова активність за термінами «foreign trade», «international trade». Отже, в результаті висновків за цим аналізом для подальшого 
дослідження використано такі ключові слова: «trade policy» та «foreign trade», за якими здійснено бібліометричний аналіз у наукометричній базі Scopus щодо актуальності питання зовнішньоторговельної політики в світі. Основною метою цього аналізу є виявлення тенденцій розвитку наукових досліджень у динаміці (за роками), за тематичними напрямами, за галузями досліджень та за географічним напрямом. На нашу думку, такий підхід у науці дозволить окреслити особливості предметних характеристик зовнішньоторговельної політики як об'єкта наукових досліджень.

На початку акцентовано увагу на географічному розмежуванні досліджуваної тематики (рис. 2) та обгрунтовано місце українських науковців у цій сфері. В наукометричній базі Scopus публікаційна активність вчених у різних країнах за досліджуваною тематикою різниться. Найбільша кількість статей опублікована в: США (24,4 \%), Китаї (6,7 \%), Австралії (4,6 \%), Німеччині (4,1 \%), Канаді $(4,0 \%)$, Франції (2,9 \%), Російській Федерації (2,9 \%), Італії (2,4 \%), Японії (2,4 \%), Швейцарії $(2,3 \%)$, Бельгії (2,2 \%), Нідерландах (2,1 \%), Іспанії (1,8 \%), Індії (1,8 \%) тощо. Кількість публікацій українських дослідників становить 23 (0,4 \%). Найбільш ранні публікації (період з 1974 по 1985 рр.) були в таких країнах як: США, Великобританія, Аргентина, Канада, Чилі. Аналізуючи динаміку публікаційної активності (рис. 2), використано для порівняння показник обсягу світової торгівлі.

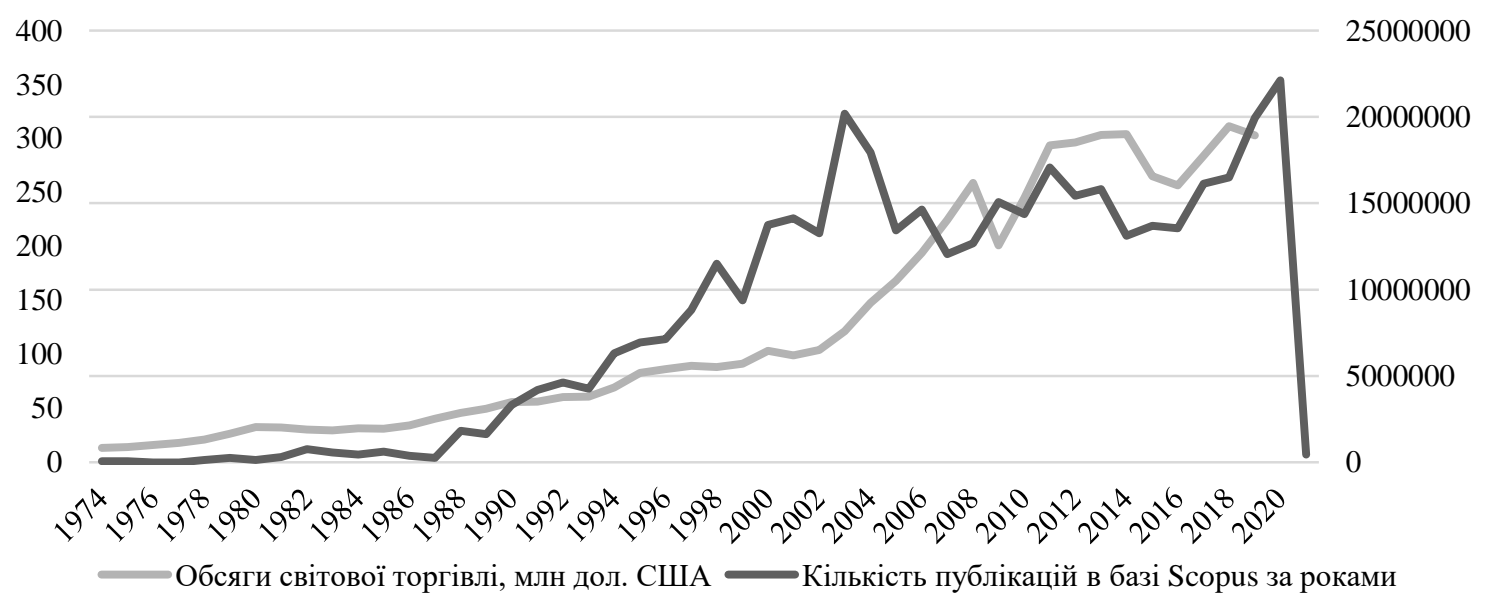

Джерело: побудована на основі даних www.scopus.com.

\section{Рис. 2. Кількість публікацій у базі Sсориз за роками за словами «trade policy» $i$ «foreign trade»} та обсяги світової торгівлі

Як бачимо, позитивна тенденція зростання кількості публікацій у базі Scopus за досліджуваною тематикою підтверджується тим фактом, що дослідження в сфері публічного управління активізувалися в 80-х роках XX ст. Крім того, в окремих роках науковці активніше публікують результати своїх досліджень (наприклад, 2003, 2011, 2017, 2020), що свідчить про існування в ці періоди підвищеної зацікавленості в науковому середовищі. В цілому за досліджуваний період найбільше статей опубліковано за такими галузями, як: економіка, економетрика та фінанси (25\%) та соціальні науки (24 \%), що становить майже половину наукових досліджень у сфері зовнішньоторговельної політики (рис. 3). Однак, якщо аналізувати конкретні роки, то ситуація змінюється.

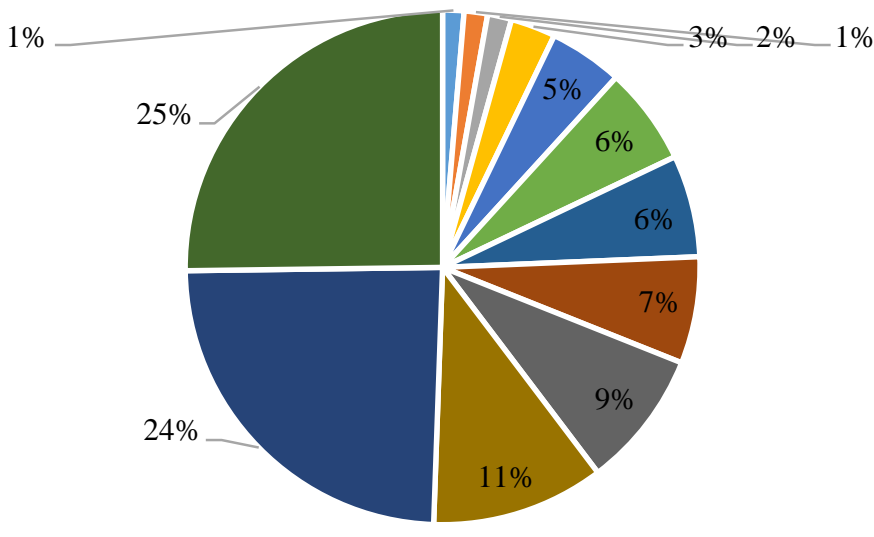

Джерело: побудована на основі даних www.scopus.com.
- Computer Science

- Arts and Humanities

- Energy

- Earth and Planetary Sciences

- Materials Science

- Chemical Engineering

- Engineering

- Agricultural and Biological Sciences

- Environmental Science

- Business, Management and Accounting

- Social Sciences

- Economics, Econometrics and Finance

Рис. 3. Кількість публікаџій в базі Scopиs за галузями дослідження за словами «trade policy» та «foreign trade» 
Так найстаріші дослідження (1974-1979 рр.) присвячені розкриттю проблем зовнішньої торгівлі та формуванню напрямів зовнішньої політики країн світу в сфері наук про навколишнє середовище та наук про землю і планети. Tucker J.C. [17] в 1974 р. досліджував причини зміни зовнішньоторговельної політики уряду США (девальвація долара та інші інструменти держави щодо стимулювання промисловості в частині зростання експорту). Comyns Carr R. [7] в 1979 р. теж звертав увагу на девальвацію грошової маси, яка допомогла зберегти економіку, та прискорення зовнішньої торгівлі як чинника економічного зростання в Іспанії. Trzeciakowski W. [16] описував практичне застосування моделей прийняття рішень для оптимізації обсягів, товарної структури та географічного розподілу зовнішньої торгівлі, а також розглянув процес прийняття рішень у соціалістичній плановій економіці. Lamphear F.C., Riefler R.F. [13] досліджували взаємозв'язок між зовнішньою торгівлею та розвитком сільських територій.

У наступний період досліджень (1980-1985 рр.) переважають праці, що розкривають сферу наук про інженерію (44 \%). Представлені роботи характеризують ринок високотехнологічної продукції та можливості відкритої торгівлі, тобто лібералізацію торговельних відносин між країнами світу: Zhang Yungchun називає чинником зростання національної економіки Китаю зростання зовнішньої торгівлі в текстильній промисловості; Moore James Р. розглядає роль федерального уряду США у високотехнологічній торгівлі та звертає увагу на необхідність відкриття ринків високотехнологічних продуктів Японії. Велику увагу в цей період приділяють науковці пластмасовій промисловості та їі ролі в розвитку машинобудування (Данія - Nyborg Ulla; Німеччина - Spamer P.); нафтовій промисловості (Франція - Henri Dominique).

Цікавим є дослідження Cooper Michael [8], який прогнозує, що в XXI ст. Китай стане промисловою державою, що конкурує як із США, так і з Японією та визначає необхідність проникнення західних компаній на ринок Китаю. Крім того, Barreda William E. [5] обгрунтовує три принципи торговельної політики США: підтримка відкритих ринків, боротьба 3 недобросовісною торгівлею та керівництво багатосторонньою лібералізацією торгівлі.

З 1986 по 1995 рр. відбувалося формування лібералізаційних торговельних режимів у багатьох країнах світу. В результаті цього спостерігалося поступове зростання експорту та імпорту. Це супроводжувалося виробленням нових підходів в управлінні державними економічними процесами, зокрема i в сфері зовнішньоторговельної політики. Тому нами виокремлено наступний етап розвитку наукових досліджень у сфері зовнішньоторговельної політики (1986-1994рр.), в якому велику увагу науковці приділяють таким поняттям, як: лібералізація, відкрита економіка, протекціонізм тощо, а також розглядають вплив формування міжнародних організацій (Свропейський Союз, Організація економічного співробітництва та розвитку, Світовий банк та ін.) на світову торгівлю. Вагому частку в наукових дослідженнях аналізованого періоду займають праці, які розкривають відносини між різними країнами світу: торговельні тертя в останні роки між Кореєю та Сполученими Штатами - Kuznets P.W., японсько-радянські далекосхідні торговельні відносини - Rehbein R.E., порівняння даних про торгівлю Великобританії та Індії - Banerjee D.

Nelson D. [15] у своїй роботі розглядає питання розвитку нового інституційного визначення торговельної політики, що дозволяло домінування виконавчої влади у торговельній політиці. Натомість Winglee P. [18] звертає увагу на переваги лібералізації та обгрунтовує негативний вплив політики підтримки сільського господарства в промислових країнах на великий глобальний дисбаланс та неправильний розподіл ресурсів.

Разом зі створенням Свропейського Союзу в 1993 р. активізувалися дослідження зовнішньоторговельної політики СС: Cerna J. [6] підкреслює неминучість процесів лібералізації у світовій економіці та зауважує, що ЄС проголошує ідею лібералізації світової торгівлі, однак часто займає позицію протекціонізму; Baneth J. [4] аналізує, що імпорт до ЄС із країн, що не входять до ЄС, зростає швидше, ніж торгівля всередині ЄС, оскаржуючи твердження про «фортецю Європи», а також зауважує, що протекціоністські заходи діяли швидше як незначні подразники, ніж як справжні перешкоди.

Після 1990 р. почали з'являтися праці в сфері формування торговельної політики з врахуванням ii впливу на екологію (Low P., Safadi R., Klepper G., Low P., Lopez R.). Також дослідники піднімають спроби сформувати перспективи розвитку зовнішньоторговельної політики та надання рекомендацій країнам, що розвиваються. На цій підставі відбувається розвиток міжнародних торговельних відносин та виникає необхідність створення міжнародної організації, яка буде пропагувати подібні правила та розвивати ліберальні недискримінаційні принципи вільної торгівлі. В 1995 р. задля лібералізації міжнародної торгівлі та регулювання торгово-політичних відносин країн-членів створено таку організацію - Світова організація торгівлі (далі - СОТ). Тому нами виокремлено наступний етап розвитку наукових досліджень - 31995 по 2007 pр. Найбільше досліджень у цей період присвячено зовнішньоторговельній політиці, що пов'язані 3 маркетингом, формуванням цін на товари, економічним умовам ведення торгівлі, встановленням тарифів у зовнішній торгівлі, конкуренцією та лібералізацією торгівлі. Також у світлі вирішення різних проблем світового торговельного середовища науковці розглядають СОТ та членство країн у найбільшій торговельній організації світу. 
Langhammer R.J., Lücke M. [14] звертають увагу на те, що вимоги вступу до COT в окремих випадках не $є$ зрозумілими для всіх країн, які мають наміри стати членами цієї організації. Автори пропонують створювати більше адміністративних та навчальних ресурсів, присвячених приєднанню не тільки в секретаріаті COT, але i 3 боку нинішніх членів та заявників. Окрім необхідності посилення адміністративного потенціалу, наводиться набір основних правил, які можуть застосовуватися до всіх переговорів про вступ, і отже, можуть допомогти впорядкувати цей процес. Також ставиться питання лібералізації торгівлі та швидкого приєднання до СОТ із терміном поступової лібералізації, що розширюється в майбутньому. На думку авторів, це - краще, ніж тривалі переговори про вступ, які зупиняють будь-який прогрес у лібералізації. Laird S. [12] порівнює політику COT та правила ГАТT і робить висновок, що організація посилила міжнародну дисципліну і надає більш обгрунтовані пояснення щодо формування експортної політики.

Важливим питанням залишається вплив торгової політики розвинених країн на світову систему торгівлі. Тому науковці звертають увагу на такі країни, як Китай (Whalley J.), Японія (Araki I.), країни Європейського Союзу (Richez-Baum B.), США.

У період з 2008 по 2015 рр. велика увага приділяється тарифам у торгівлі. Також в цей період актуальності набуває питання курсу валют та їх впливу на торговельні відносини в світі, встановлення цін на товари та проблеми ліквідності підприємницької діяльності (Keidel A., Thorstensen V., Marçal E., Ferraz L., Orbay H., Orbay B.Z.). Цікавим з дослідницької точки зору є питання аналізу політики, що також 3'являється в наукових статтях у цей період часу (Dorosh P. i Salam A., Warr P., Klimenko M.M., Antràs P., Padró i Miquel G.).

Наступним етапом є період досліджень з 2016 р. по даний час (2020 р.), коли з'являються сучасні проблеми регулювання зовнішньої торгівлі та виклики для підприємництва: управління ланцюгами поставок (Galeshi M.R.); участь країн у глобальних ланцюгах створення вартості (Cieślik E., Biegańska J., Środa-Murawska S., Araújo S., Flaig D.); діджиталізація торгівлі; торговельні війни (Тam P.S., Fusacchia I., An J., Mikhaylov A., Richter U.H.), що супроводжується ризиками зовнішньоторговельної діяльності (Binh N.X.).

Під час здійсненого аналізу напрямів наукових досліджень у наукометричній базі Scopus виявлено окремі тенденції розвитку проблемних питань у сфері зовнішньоторговельної політики в різних країнах світу. Для візуалізації отриманих результатів дослідження нами використано програму VOSviewer [9], яка дозволяє зобразити результати аналізу у вигляді термінологічної карти на основі ключових слів, що зустрічаються в проаналізованих статтях (рис. 4).

Всі публікації за темою дослідження

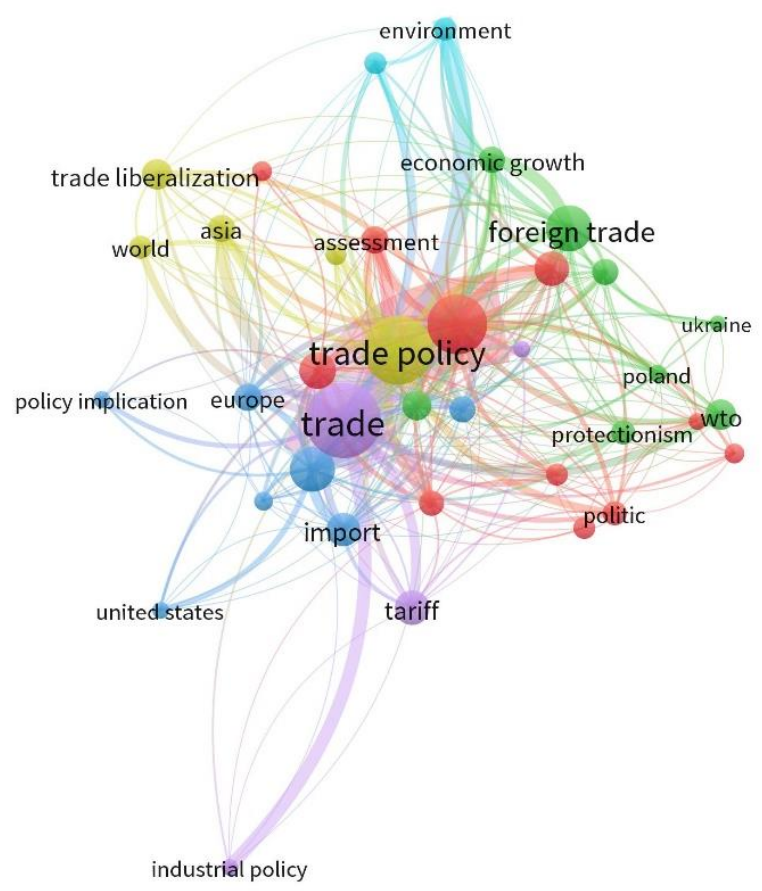

Публікації з ключовим словом «Україна»

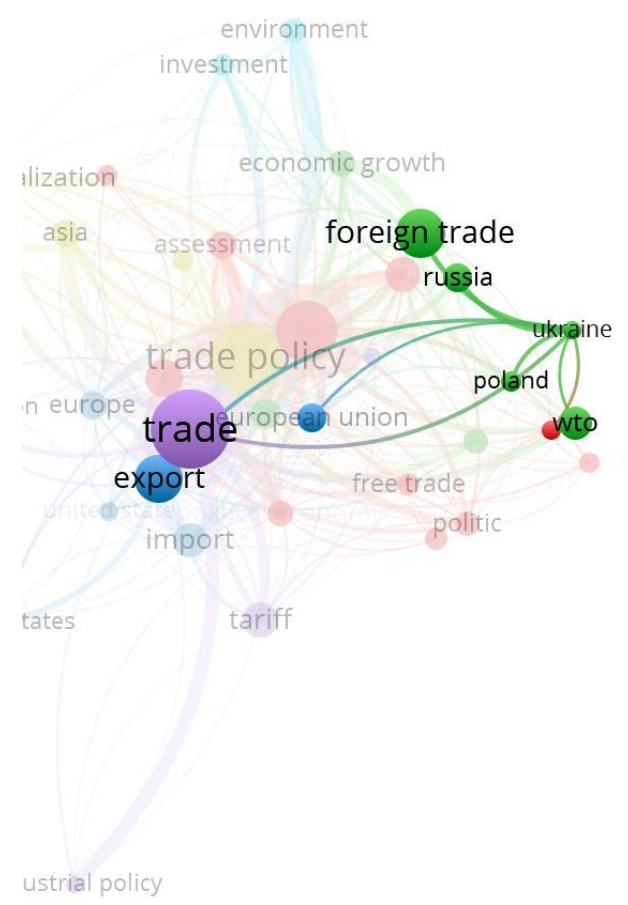

Джерело: побудовано за допомогою програми VOSviewer

Рис. 4. Термінологічна карта наукових статей у наукометричній базі Scopиs у сфері зовнішньоторговельної політики за період 1974-2020 рр. 
Побудована карта виявляє частоту вживання термінів (що позначається відповідною формою кола), тісноту зв'язку між ними (чим ближче терміни один до одного, тим тісніше зв'язок) і різні варіанти використання термінів у наукових дослідженнях. Як бачимо, наукові дослідження можна умовно поділити на 6 кластерів, яким запропоновано такі тематичні назви: світова торговельна політика; зовнішня торгівля СС та США; наслідки зовнішньої торгівлі на соціо-еколого-економічну світову систему; стратегічні напрями розвитку зовнішньої торгівлі; принципи СОТ та політика країн-учасниць; політика протекціонізму (тарифні та нетарифні методи).

Наступним етапом дослідження є аналіз публікацій в наукометричній базі Scopus, що висвітлюють питання, пов'язані із зовнішньоторговельною політикою України. Серед зарубіжних науковців: Hoekman B., Jensen J., Tarr D. [11] розкривають питання участі України в міжнародному торговельному середовищі. Автори дослідження припускають, що торгова політика, яка є глобальною у перспективі, та зниження торгових витрат є критично важливими для України, і що зусилля мають бути зосереджені на вирішенні конкретних областей політики, які негативно впливають на торгівлю 3 митними союзами Росії та ЄС. Натомість авторами більшості наукових праць є українські дослідники (табл. 1).

Напрями досліджень у сфері зовнішньоторговельної політики, щ⿻о здійснювалися украйнськими науковиями в період 2001-2020 рр. та опубліковані в наукометричній базі Scopиs

\begin{tabular}{|c|c|}
\hline Напрями досліджень & Науковичі \\
\hline $\begin{array}{l}\text { Аналіз зовнішньоторговельної діяльності України } \\
\text { (динаміка, товарна та географічна структура, } \\
\text { диверсифікація експорту та імпорту) із } \\
\text { застосуванням методів моделювання, } \\
\text { економетричного аналізу, структурного та } \\
\text { динамічного аналізу }\end{array}$ & $\begin{array}{l}\text { Mikhalevich M.V., Sergienko I.V., Koshlai L.B., } \\
\text { Shepotylo O., Bodnar R.D., Melnyk T., } \\
\text { Vyshynska T., Shtal T.V., Polyakova Y.O., } \\
\text { Proskurnina N.V., Dobroskok I.B., Kot O.V., } \\
\text { Krasnoded T., Popova T., Bakina T., Vasylchenko O. }\end{array}$ \\
\hline $\begin{array}{l}\text { Фактори дестабілізації української зовнішньої } \\
\text { торгівлі }\end{array}$ & $\begin{array}{l}\text { Kudyrko L.P., Volosheniuk V.V., } \\
\text { Khapatniukovskyi M.M., Götz L., } \\
\text { Djuric I., Nivievskyi O. }\end{array}$ \\
\hline $\begin{array}{l}\text { Інституційні механізми державного регулювання } \\
\text { зовнішньоекономічної діяльності }\end{array}$ & Lyakhova O., Urvantseva S. \\
\hline $\begin{array}{l}\text { Економічні механізми державного управління } \\
\text { зовнішньоторговельною діяльністю }\end{array}$ & $\begin{array}{l}\text { Melnyk T., Golovachova O., Shepotylo O., Koval N., } \\
\text { Luchenko D. }\end{array}$ \\
\hline Маркетинг у сфері українського експорту & $\begin{array}{l}\text { Lyashenko V., Osadcha N., } \\
\text { Galyasovskaya O., Knyshek O. }\end{array}$ \\
\hline Ризики зовнішньоторговельної політики України & $\begin{array}{l}\text { Yatsenko O., Nitsenko V., Mardani A., } \\
\text { Streimikiene D., Tananaiko T., Raišienè A.G., } \\
\text { Yatsenko O., Nitsenko V., Karasova N., } \\
\text { Vojtovicova A., Koval N., Luchenko D. }\end{array}$ \\
\hline Зовнішньоекономічний потенціал регіону & $\begin{array}{l}\text { Gudz P., Oliinyk Y., Shkurupska I., } \\
\text { IvanchenkovV., Petrenko O., Vlasenko Y. }\end{array}$ \\
\hline $\begin{array}{l}\text { Зовнішньоторговельний оборот між Україною та } \\
\text { Польщею }\end{array}$ & Motoryn R., Prykhodko K., Slusarczyk B. \\
\hline $\begin{array}{l}\text { Валютний курс та його вплив на зовнішню } \\
\text { торгівлю України }\end{array}$ & Oliinyk O., Ksendzuk V., Sergiienko L., Lehan I. \\
\hline
\end{tabular}

Джерело: узагальнено на основі даних www.scopus.com.

Дослідження українських науковців розкривають питання державного регулювання зовнішньоторговельної діяльності від аналізу показників розвитку зовіншньої торгівлі до механізмів управління. Натомість світові тенденеції розвитку міжнародної торгівлі та формування підходів до ведення зовнішньої політики впливають на національні інтереси окремих країн, визначаючи перспективні напрями їх розвитку.

Висновки та перспективи подальших досліджень. Під час проведеного дослідження виокремлено етапи та надано характеристику напрямам дослідження в міжнародній наукометричній базі Scopus у сфері публічного управління зовнішньоторговельною діяльністю. На кожному з етапів дослідження окреслено предметно-об'єктно сферу зовнішньоторговельної політики та виокремлено актуальні питання дослідження. За допомогою методу бібліометричного аналізу наукових досліджень та з використанням програми VOSviewer побудовано термінологічну карту наукових статей у наукометричній базі Scopus y сфері зовнішньоторговельної політики за період 1974-2020рр. На цій підставі проаналізовано зв'язки між основними ключовими термінами, що зустрічаються в досліджуваній тематиці, та сформовано 6 кластерів 
(світова торговельна політика; зовнішня торгівля СС та США; наслідки зовнішньої торгівлі на соціоеколого-економічну світову систему; стратегічні напрями розвитку зовнішньої торгівлі; принципи СОТ та політика країн-учасниць; політика протекціонізму (тарифні та нетарифні методи)).

Отже, дослідження питань зовнішньоторговельної політики та механізмів державного управління тісно пов'язане з такими сферами, як: зовнішня торгівля (міжнародні економічні відносини), зовнішня політика (міжнародні відносини) та державне управління. Завданням публічного сектору є формування ефективних механізмів державного управління зовнішньоторговельною діяльністю на підставі виявлення проблемних питань у сфері зовнішньої торгівлі та застосування результатів зовнішньої політики країни.

\section{Список використаної літератури:}

1. Бредихин C.B. Методы библиометрии и рынок электронной научной периодики / C.В. Бредихин, А.Ю. Кузнеиов. - Новосибирск : ИВМиМГ СО РАН, НЭКОМ, 2012. - 256 с.

2. Мазур B.A. Використання міжнародних наукометричних баз даних Web of Science та Scopus для наукових досліджень в аграрних закладах вищої освіти / В.А. Мазур, К.В. Мазур, Г.В. Панцирева // Економіка. Фінанси. Менеджмент: актуальні питання науки і практики : зб. наук. пр. ВНАУ. - 2019. - № 4. - С. 83-91 [Електронний ресурс]. - Режим доступу : http://repository.vsau.org/getfile.php/21912.pdf.

3. Медведєва А. Бібліометричні системи як інструмент моніторингу та підтримки досліджень / А.Медведєва // Наукові праці Національної бібліотеки України імені В.I. Вернадського. - 2017. - №. 48. - С. 384-395 [Електронний ресурс]. - Режим доступу : http://nbuviap.gov.ua/index.php?option=com_content\&view=article\&i d=3483:bibliometrichni-sistemi-yak-instrument-monitoringu-ta-pidtrimki-doslidzhen\&catid=81\&Itemid=415 .

4. Baneth J. «Fortress Europe» and other myths about trade: policies toward merchandise imports in the EC and other major industrial economies (and what they mean for developing countries) / J.Baneth // World Bank Discussion Papers. - 1993. - P. 225.

5. Barreda William E. Administration trade policy / E.Barreda William // Materials and society. - 1985. - Vol. 10 (2). P. 213-215.

6. Cerna J. Protectionism versus liberalism in the EC / J.Cerna // Ekonomicky Casopis. - 1993. - Vol. 41 (11-12). P. 831-843.

7. Comyns Carr R. Spain's economy - the miracle and after / R.Comyns Carr // National Westminster Bank Quarterly Review. - 1979. - P. 66-74.

8. Cooper M. China: marketing opportunities / M.Cooper. -1985.

9. Van Eck N.J. Software survey: VOSviewer, a computer program for bibliometric mapping / N.J. Van Eck, L. Waltman // Scientometrics. - 2010. - Vol. 84, № 2. - P. 523-538.

10. Google trends [Електронний pecypc]. https://trends.google.ru/trends/explore?date=all\&q=trade\%20policy,foreign $\% 20$ trade,foreing\%20policy

11. Hoekman B. A vision for Ukraine in the world economy: Defining a trade policy strategy that leverages global opportunities / B.Hoekman, J.Jensen, D.Tarr // Journal of World Trade. - 2014. - Vol. 48 (4). - P. 795-814.

12. Laird S. Export policy and the WTO / S.Laird // Journal of International Trade and Economic Development. - 1999. Vol. 8 (1). - P. 73-88.

13. Lamphear F.C. Foreign imports and nonmetropolitan growth / F.C. Lamphear, R.F. Riefler // Regional Science Perspectives. - 1979. - Vol. 2. - P. 49-71.

14. Langhammer R.J. WTO accession issues / R.J. Langhammer, M.Lücke // World Economy. - 1999. - Vol. 22 (6). P. 837-873.

15. Nelson D. Domestic political preconditions of us trade policy: Liberal structure and protectionist dynamics / D.Nelson // Journal of Public Policy. - 1989. - Vol. 9 (1). - P. 83-108.

16. Trzeciakowski $W$. Indirect management in a centrally planned economy system constructions in foreign trade / W.Trzeciakowski. -1978

17. Tucker J.C. Overseas marketing problems / J.C. Tucker // SAE Technical Papers. - 1974.

18. Winglee P. Agricultural trade policies of industrial countries / P.Winglee // Finance \& Development. - 1989. Vol. 26 (1). - P. 9-11.

\section{References:}

1. Bredikhin, S.V. and Kuznetsov, A.Yu. (2012), Metody bibliometrii i rynok elektronnoi nauchnoi periodiki, IVMiMG SO RAN, NEKOM, Novosibirsk, 256 p.

2. Mazur, V.A., Mazur, K.V. and Pancyreva, G.V. (2019), «Vykorystannja mizhnarodnyh naukometrychnyh baz danyh Web of Science ta Scopus dlja naukovyh doslidzhen' v agrarnyh zakladah vyshhoi' osvity», Ekonomika. Finansy. Menedzhment: aktual'ni pytannja nauky i praktyky, zb. nauk. pr. VNAU, No. 4, pp. 83-91, [Online], available at: http://repository.vsau.org/getfile.php/21912.pdf

3. Medvedjeva, A. (2017), «Bibliometrychni systemy jak instrument monitoryngu ta pidtrymky doslidzhen'», Naukovi praci Nacional'noi' biblioteky Ukrai'ny imeni V.I. Vernads'kogo, No. 48, pp. 384-395, [Online], available at: http://nbuviap.gov.ua/index.php?option=com_content\&view=article\&id=3483:bibliometrichni-sistemi-yakinstrument-monitoringu-ta-pidtrimki-doslidzhen\&catid=81\&Itemid $=415$

4. Baneth, J. (1993), «Fortress Europe» and other myths about trade: policies toward merchandise imports in the EC and other major industrial economies (and what they mean for developing countries)», World Bank Discussion Papers, P. 225. 
5. Barreda, William E. (1985), «Administration trade policy», Materials and society, Vol. 10 (2), pp. 213-215.

6. Cerna, J. (1993), «Protectionism versus liberalism in the EC», Ekonomicky Casopis, Vol. 41 (11-12), pp. 831-843.

7. Comyns Carr, R. (1979), «Spain's economy - the miracle and after», National Westminster Bank Quarterly Review, pp. 66-74.

8. Cooper, M. (1985), China: marketing opportunities.

9. Van Eck, N.J. and Waltman, L. (2010), «Software survey: VOSviewer, a computer program for bibliometric mapping», Scientometrics, Vol. 84, No. 2, pp. 523-538.

10. Google trends, [Online], https://trends.google.ru/trends/explore?date=all\&q=trade $\% 20$ policy,foreign $\% 20$ trade,foreing $\% 20$ policy

11. Hoekman, B., Jensen, J. and Tarr, D. (2014), «A vision for Ukraine in the world economy: Defining a trade policy strategy that leverages global opportunities», Journal of World Trade, Vol. 48 (4), pp. 795-814.

12. Laird, S. (1999), «Export policy and the WTO», Journal of International Trade and Economic Development, Vol. 8 (1), pp. 73-88.

13. Lamphear, F.C. and Riefler, R.F. (1979), «Foreign imports and nonmetropolitan growth», Regional Science Perspectives, Vol. 2, pp. 49-71.

14. Langhammer, R.J. and Lücke, M. (1999), «WTO accession issues», World Economy, Vol. 22 (6), pp. 837-873.

15. Nelson, D. (1989), «Domestic political preconditions of us trade policy: Liberal strcture and protectionist dynamics», Journal of Public Policy, Vol. 9 (1), pp. 83-108.

16. Trzeciakowski, W. (1978), Indirect management in a centrally planned economy system constructions in foreign trade.

17. Tucker, J.C. (1974), «Overseas marketing problems», SAE Technical Papers.

18. Winglee, P. (1989), «Agricultural trade policies of industrial countries», Finance \& Development, Vol. 26 (1), pp. 9-11.

Олійник Оксана Вікторівна - доктор економічних наук, професор, перший проректор Державного університету «Житомирська політехніка».

Наукові інтереси:

- теорія, методологія та методика аналізу.

Ксендзук Валентина Віталіївна - кандидат економічних наук, доцент, доцент кафедри економічної безпеки, публічного управління та адміністрування Державного університету «Житомирська політехніка».

Наукові інтереси:

- зовнішньоторговельна політика України;

- участь України в міжнародних організаціях. 